\title{
Hamas vs. Global Jihad Organizations: Rivals or Partners
}

\author{
Shaul Bartal \\ Bar-Ilan University, Ramat Gan, Israel
}

\begin{abstract}
Hamas is the Palestinian branch of the Global Muslim Brotherhood movement. Hamas emphasizes its nationalistic aspects and not just the Islamic ones. The Palestinian Abdullah Yusuf Azzam, Osama Bin Laden's mentor, is the link between the global jihad organizations and Hamas. Global jihad organizations like ISIS or al-Q'aida represent opposite points of view to those of the Muslim Brotherhood. First and foremost, they are not nationalistic but Pan-Islamic Movements. Islamic organizations cannot be described by ideas such as nationalism, socialism or any other set of secular ideas. Understanding Islamic organizations means understanding their religious roots. This article presents the argument that even Hamas, usually described as a nationalistic movement, can be identified as a Global Jihad organization which combines nationalistic elements.
\end{abstract}

Keywords: Hamas, ISIS, al-Q'aida, Israel, Muslim Brotherhood, Global Jihad, Osama Bin Laden, Abdullah Azzam

Friday, November 24th is a special day in Hamas and al-Qaida history alike. This date denotes the strong ties between the Hamas organization and Global Jihad which are represented by al-Qaida and the Islamic state. Why is this date so important? What exactly are the connections between Global Jihad and Hamas?

Hamas (Harakat al-Muqawama al-Islamiyya-Islamic Resistance Movement) is, according some studies, a national liberation movement. Katrina Dalacoura (2011) put it this way:

Islamist movements are political entities and, as such, employ and interpret doctrine and beliefs in a flexible and inventive manner. Islamist ideology is not inherently and necessarily opposed to any set of ideas, including nationalism, but dynamically interacts with them. (p. 66)

Are they? This article presents the deep ideological aspects of Hamas. It also presents the global aspirations of Hamas (as part of the Muslim Brotherhood) similar to that of the other global jihad organizations. Islamic organizations cannot be described by ideas, such as nationalism, socialism or any other set of secular ideas. Understanding Islamic organizations means understanding their religious roots. This article presents the argument that even Hamas, usually described as a nationalistic movement (Dalacoura, 2011; Chehab, 2007; Singh, 2011; Calvert, 2010), can be identified as a global jihad organization which combines nationalistic elements.

\section{The Martyrdom Legacy}

A culture of martyrdom and suicide attacks is common in al-Qaida and ISIS but the pioneers of the massive use of this tactic were Hamas and the Islamic Jihad. Suicide bombings are neither a cheap weapon nor the spontaneous, organic expression of the inchoate rage of people. It is tactic adopted for specific strategic

Shaul Bartal, Dr., military analyst; a lecturer, Department of Middle Eastern Studies, Begin-Sadat Center for Strategic Studies, Bar-Ilan University, Ramat Gan, Israel. 
reasons by terrorists which involve the commitment of significant resources in order to be successful.

We now return to the first question: Why is November 24th such an important date for both Hamas and the global jihad organizations?

The reason is that it is the common memorial day for Sheikh Abdullah Yusuf Azzam (died November 24, 1989), who, together with Usāmah Bin Lādin, founded the al-Qaida movement in 1988, and Emed Akel (died November 24, 1993), one of the founders and commanders of the Izz ad-Din al-Qassam Brigades, the military wing of the Hamas organization.

Abdullah Yusuf Azzam was a Palestinian from the Jenin area. Between 1968 and 1970, he fought Israel through infiltration activities and by planting mines inside of Israel. He became a lecturer of Islamic studies in Saudi Arabia where he met his student and future partner Usāmah Bin Lādin. In 1979, due to the Soviet invasion of Afghanistan, Azzam began preparing cadres of Muslim Arabs to fight in order to liberate Muslim countries. His stand among the Muslim Brotherhood in Palestine influenced many in regard to the formation of Hamas. Even today, there are those who believe that he was directly involved with the organization's founding in 1987. It was Azzam's opinion that jihadist organizations could aspire to free occupied lands in all of the Muslim lands and receive aid from the Muslim Brotherhood to help them do this. The land would then be freed and the jihad requirement would be met (Walberg, 2015). Palestine was a side project to his Afghan activities (Hegghammer, 2013). From his base in Pakistan, Azzam supported Hamas politically, financially and logistically. The Afghanistan mujahideen success in expelling the Soviets in 1989 created an amazing incentive and hoped that perhaps Hamas in Palestine would also succeed, through constant military pressure, in bringing about the destruction of the State Israel and the return of Palestine to its legal owners, read Palestinians (Hegghammer, 2013).

In Azzam's last book about the Hamas organization, Hamas, Historical Roots and the Charter, he emphasized the importance of the organization as part of the Islamic reawakening and supported and encouraged the organization's founding ('Azzam, 1990a). In his last book, he wrote:

Your life is jihad, your glory is in jihad and our presence is fatefully connected through the jihad way...because the jihad is the only guarantee that watches over the rites [of Allah] and the house of his servants. And were it not that Allah checks the people some by means of others, there would be monasteries, churches, synagogues and mosques in which the name of Allah is much mentioned which would have been demolished... (Bartal, 2016, pp. 21-22) ${ }^{1}$

Emed Akel fulfilled the will of Abdullah Azzam. However, except for the similarity in the date of their death, can one actually say, as Hamas activists claim, that Emed Akel was Azzam's student and the one who followed in his footsteps?

In an official publication of the Izz ad-Din al-Qassam Brigades, Northern Branch, The Competitors for Heaven, which was written by Hussam Badran, an activist in the Hamas organization and the Hamas representative in Lebanon, the writer presents the Hamas world outlook which espouses the Martyr Death of "Our Palestinian Nation and our Islamic Faith". The introduction to the book was written by Khālid Mash'al, the former head of Hamas' Political Bureau (until 2017). In the introduction, Mash'al relates to the importance of jihad and "Martyr's Death". Mash'al praises the Hamas dead who strived to make contact with the enemy while they were "objecting to the occupiers through suicidal sacrifice, ambushes, breaching through to the

\footnotetext{
${ }^{1}$ Palestinian Islamic Jihad pamphlet, Wasiyah Batel al-Qima fi 'Aser al-Inhirar, Wasiyah al-'Alam al-Mujahid, Saber li-Allah Madherm ila Umat al-Islam (Kuwait: Dar al-Nafees, n.d.), pp. 23-24; quoted and translated in Bartal (2016, pp. 21-22).
} 
settlements and sending al-Qassam missiles". According to Mash'al, with their deeds they "were granted a martyr's death and won the race to Paradise..., continued the jihad way and the opposition and continued the history of our brave nation generation after generation".2

The book is only an expression, one of many, made by the senior leadership of Hamas that glorifies the "martyr's death". Their struggle is not only for the Palestinian people but also for the entire Islamic nation.

\section{Hamas and the Global Islamic Organizations: Brothers on the Same Path or Rivals?}

According to its publicity, the Hamas organization was officially founded on December 14, 1987. Since its establishment, the organization has turned into a leader in the field in terms of opposition activities (al-Muqawama) against Israel. The al-Qaida organization, headed by Abdullah Azzam and Usāmah ibn Muhammad ibn 'Awậ̣ ibn Lādin, was actually created in 1988 as the reincarnation of Maktab al-Khidamat

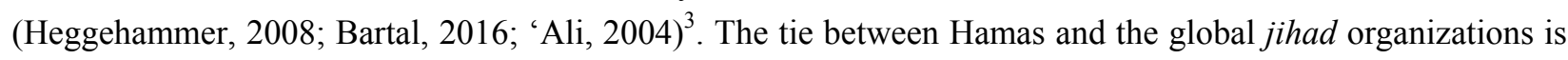
a close, productive, and complicated tie. Sometimes it is a tie of bitter rivalry and sometimes it is a tie of cooperation out of similar interests, such as the Israel-Arab conflict, a fight supported by a broad consensus throughout all of the Islamic lands. Hamas and the global jihad organizations have common roots and could be described as al-salafaiyya al-Qataliyya (fighting salafi groups) according to Baker abu Baker (2016) .

Azzam entered into difficult disagreements with 'Ayman Muḥammad az-Ẓawāhirī, and Usāmah Bin Lādin over this matter. After the expulsion of the Soviets from Afghanistan, Azzam wished to focus on Palestine and battles against Israel. Usāmah Bin Lādin preferred to widen the jihad against the United States and Ayman Zawahiri wished for jihad against the Arab infidel states, such as Husni Mubarak's Egypt (Walberg, 2015).

Sheikh Salah al-Aruri, the founder of the military arm of the Hamas organization in the West Bank, admired Azzam's attitude toward jihad. This is the reason why he founded the Abdullah Azzam Brigades in the West Bank (that later became the Izz ad-Din al-Qassam Brigades). He believed that the Iranian Revolution and the war in Afghanistan were central milestones in creating awareness for military action among the Palestinian Muslim Brotherhood in order to change the balance of power in the Israeli-Arab conflict. Azzam's ideological influence on Hamas definitely spurred Ahmad Yassin and his friends on to a military path (already in the 80s even before Hamas was officially founded) (Bartal, 2016) ${ }^{4}$. The Hamas War Academy in the Gaza Strip is also named after Abdullah Azzam.

On the ideological plane, Hamas, al-Qaida, and ISIS are apparently on the same side. Hamas, like all of the fundamentalist Islamic organizations, desires an Islamic Caliphate that will unite all of the Islamic countries; caliphs who will bring back the glory to Islam that existed in the 7th century from the days of the Golden Age of the Islamic Empire. All of the Islamic philosophers, such as Hassan al-Bannah, the founder of the Muslim Brotherhood organization; Sayyid Qutb and even Ruhollah Mūsavi Khomeini, an Iranian Shia Muslim religious leader, preached for Islamic unity on the basis of world Islamic faith and not on the basis of modern nationalism and artificial borders determined in the 18th century by the European imperialists (Walberg, 2015).

Although Hamas highlights its unique Palestinian identity, this emphasis does not contradict its existence as part of the wider Islamic identity of the Muslim Brotherhood. It is therefore not surprising when Hamas

\footnotetext{
2 Hussam Badran, Katiba al-Shimal, al-Sabiqun ila al-Jina (no details, published by Izz ad-Din al-Qassam, 2010), pp. 4-6.

3 Maktab al-Khidamat was founded in 1984. For more information regarding Abdu'llāh Yūsuf 'Azzām see Heggehammer (2008, pp. 81-101); Bartal (2016, pp. 9-29); and 'Ali (2004).

${ }_{4}$ See the interview with Salah al-'Aruri in Hamas Journal, Al-Qassamiyun-Majallat Kata'eb al-Shaid Izz ad-Din Al-Qassam, Sept. 22, 2011, pp. 16-17; Bartal (2016, p. 27).
} 
refuses to denounce al-Qaida or ISIS on their jihad activities—even if they hurt Muslim brothers in Iraq, Syria and other places. Hamas' excuse, according to Hamas spokesperson Sami Abu Zuhri: "There is no definition of

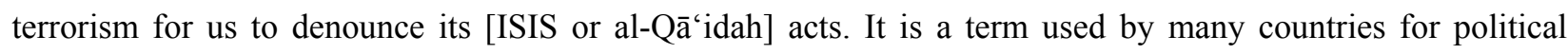
purposes" (Walberg, 2015, p. 27). This view is not surprising. Most of the al-salafaiyya al-qataliyya organizations in the Gaza Strip are former Izz ad-Din al-Qassam Brigade members who still have connections to Hamas (Baker, 2016).

Abu Zuhri stresses that Hamas is moderate and does not believe in any extremist ideology. It is not hostile toward those who do not offend it. The problem does not lie in espousing different ideologies but rather about those who try to take the law into their own hands.

Abu Zuhri relates to the battles between Hamas activists and a group of Salafists that supported al-Qaida in August 2009. Hamas forces entered the Ibn Taymiyyah Mosque and killed Abdul Latif Moussa (Abu Al-Nour al-Muqdasi) and 16 of his supporters because they announced that they were the Islamic Emirs of Jerusalem. They also blame Hamas on shirq (idol worship) because they participated in the democratic process in 2006 (Baker, 2016).

Abu Zuhri added:

We judge the credibility of any organization by the extent of its effort to face the occupation forces. Hamas is responsible for the Palestinian arena and will not take any stance toward any other non-Palestinian group as we believe that this ought to be dealt with in the concerned countries. (al-Ghoul, 2014)

One of the security officers who participated in the attack on the Ibn Taymiyyah Mosque (who only spoke under the condition of anonymity as it was a matter of great sensitivity) said:

We didn't have any problem with them [the salafaiyya al-qataliyya] as a group upholding a certain ideology. However, when they started to go out wearing explosive belts, claiming that the people and the government of Hamas are infidels, it became our duty to stop them. (al-Ghoul, 2014)

In the eyes of ISIS, Hamas is sometimes seen as an infidel organization due to its sanctifying local nationalism (Palestinian nationalism) and prioritizing them over Islamic nationalism for the nation. This philosophy also arises in interrogations of arrested Islamic ISIS activists, such as Lukman 'Atun and Khalil Khalil (Efraim, 2016; Walberg, 2015; Baker, 2016) ${ }^{5}$. Despite this, Hamas has no problem with Salafist organizations as long as they do not rebel against Hamas authority in the Gaza Strip. Hamas sees the Salafists as an Islamic organization and as a partner on the Islamic path. That is why, despite differences in opinion, Hamas will not act against or denounce the organization. After an explosion in Gaza due to ISIS activity, a top Hamas leader was interviewed for the al-Monitor news site where he explained the logic that stood behind the decision not to condemn ISIS and not to join the U.S. alliance, even in the media discourse: (Walberg, 2015; al-Ghoul, 2014)

There is a decision not to take any stance toward ISIS. We are all Islamists and it is ideologically difficult for us to condemn them as terrorists. We are accused of the same by the West and some Arab countries.

\footnotetext{
5 The above were arrested in Jerusalem after they tried to join ISIS and establish a cell that would carry out terrorist attacks in the city. Under investigation they argued that Hamas was an infidel organization that emphasized Palestinian nationalism rather that the Islamic nation. Lukman 'Atun, the head of the organization, was convicted on Dec. 22, 2016 and given 26 months in jail.
} 
Hamas leader, Ahmad Youssef, believes that not everyone who takes up arms to fight for just causes is a terrorist. He said that Hamas does not use these Western terms: "The U.S. used to call the Afghans who fought the Soviet Union mujahedeen but when they started fighting against America, they became terrorists" (Walberg, 2015, p. 99; Asmaa al-Ghoul, 2014).

In a sermon delivered in Islamabad on February 24, 1989, nine days after the retreat of Soviet forces from Afghanistan, 'Azzam detailed the modus operandi of the Worldwide Islamic Jihad Theory in its efforts to liberate Islamic soil:

We will force the world to recognize us. If it does-fantastic; if it does not-so be it. We will fight, defeat our enemies and establish an Islamic state on some sliver of land, such as Afghanistan. Afghanistan will expand, Jihad will spread, Islam will fight on in other places, Islam will fight the Jews in Palestine and establish Islamic states in Palestine, Afghanistan and other places. Later, these states will unite to form [one] Islamic state. (Maliach, 2008, p. 364)

Besides the fact that both belonged to the same parent movement, the Muslim Brotherhood, perhaps the most important common thread linking Hamas and 'Azzam was a common ideology of liberating Palestine from the Jews. A comparison of the Hamas Charter, published on August 18, 1988, and 'Azzam's views, reveals the ideological kinship between the two sides ('Azzam, 1990a; Anon, n.d.; Shabi \& Shaked, 1994). ${ }^{6}$ For example, Article 6 of the Hamas Charter affirms the group's allegiance to Allah, its goal of maintaining an Islamic way of life and its aspiration to "raise the flag of Allah over every centimeter of Palestinian soil" ('Azzam, 1990a, p. 121; 'Azzam, 1987), p. 70). Article 7 of the Charter defines Hamas as a worldwide Islamic movement whose members are spread throughout the globe and work actively to strengthen its influence. Articles 14 and 15 link the problem of the liberation of Palestine to three "circles": Palestinian, Arab, and Islamic. As a result, these clauses determine that the liberation of Palestine is an individual duty obligating all Muslims. Therefore, Articles 7, 14, and 15 create a direct link between the Hamas Charter and 'Azzam's Worldwide Islamic Jihad Theory to be discussed later ('Azzam, 1990a). Article 11 of the Charter defines Palestinian soil as Holy Ground (Waqf), which no Muslim may negotiate over or concede at any time.

This clause further defines all lands which have ever been considered "Dar al-Islam" ("House of Islam") as territory belonging eternally to Muslims ('Azzam, 1990a; 1990b). Article 12 stipulates that in the event that an enemy invades Muslim land, jihad becomes an individual duty obligating all Muslims, such that Muslims do not require anyone's permission to undertake jihad against the invaders. Article 13 defines the confrontation with the Jews over control of Palestine as a religious conflict, such that to concede any part of Palestine would be tantamount to conceding part of the Islamic faith. In effect, this clause categorically rejects all of the peace initiatives and international conferences that were designed to solve the Palestinian problem and calls for militant jihad as the only solution. Article 16 emphasizes Islamic education as an important step toward the liberation of Palestine, along with a thorough knowledge of the enemy ('Azzam, 1990a). Articles 17 and 28 point to the intense hatred held by Hamas towards Zionism and the organizations it considers to be associated with Zionism, such as Rotary International and the Alliance Israelite Universelle. Article 19 divides the world into two types of societies, Islamic and "Jahili" ("ignorant"). Article 22 accuses the Jews ("the enemies") of using their wealth to control the global media. The clause further holds the Jews responsible for past and present revolutions and wars around the world, such as the French Revolution, the Communist Revolution, and

\footnotetext{
${ }^{6}$ The issuance of the Hamas Charter was a central landmark in the movement's development. This was the first attempt to formulate an independent Palestinian-Islamic platform to counter the secular approach of the PLO. See Shabi and Shaked (1994, $p$. 107).
} 
both world wars. Furthermore, the Jews are accused of having used their wealth to secure the Balfour Declaration. Article 32 points to Zionism's aspiration to spread, referring the reader to the "Protocols of the Elders of Zion", which supposedly detailed these plans. This clause also declares Hamas to be the spearhead in the struggle against international Zionism, emphasizing the role of Arab and Islamic nations in the conflict against the Jews, whom the charter calls "Merchants of War" ('Azzam, 1990a, pp. 134-150). All of these anti-Semitic views are also common in Global Jihad propaganda (Bartal, 2017a).

An additional manifestation of Hamas' ideological identification with Worldwide Islamic Jihad can be seen in leaflets, posters, and CD-ROMs seized by the Israel Defense Forces (IDF) in the past decade in mosques and in offices of Hamas-backed charities in the West Bank. These materials show signs of admiration and identification with Usāmah Bin Lādin and the Chechen rebels and call for a continuation of militant jihad. These materials were also disseminated via Hamas websites and distributed by Hamas activists in Palestinian educational institutions as part of a campaign to cultivate the values of radical Islam and Worldwide Islamic Jihad among members of the younger generation (Maliach, 2008) ${ }^{7}$.

If his declarations are to be believed, it could be said that Bin Lādin linked his own fate with that of the Palestinians (Bin Lādin, 2001) ${ }^{8}$, and was optimistic vis- $a$-vis the chances to liberate Palestine in the future. Like his spiritual mentor 'Abdullah, 'Azzam, whose name is honored in the title of al-Qa'ida's battalions, Bin Lādin invoked the words of the Prophet Muhammad:

The hour for waking the dead will not arrive until the Muslims fight the Jews and the Muslims kill them; then the Jew will hide behind the rock or the tree, and the stone or the tree will say: Muslim, servant of Allah, behind me is a Jew, come and kill him, except for the boxthorn, which is one of the trees of the Jews. (Hanbal, 1969, p. 417) ${ }^{9}$

He quoted part of verse 32 of the "Table Spread Surah" in the Koran which discusses Cain's killing of Abel, insinuating that the killing of Palestinians (Abel) will cost the Jews (Cain) greatly: "Because of that We ordained for the Children of Israel: that whoever kills a person- unless it is for murder or corruption on earth-it is as he killed the whole of mankind" (Bin Lādin, 2001; Itani, 2014, p. 39).

On March 4, 2006, al-Jazeera aired a videotape of Ayman al-Zawahiri. On the tape, he criticized the West's stance concerning Islam and the publication of caricatures of Muhammad in Western newspapers. He called upon the Hamas government to reject the treaties signed with Israel and continue its militant jihad against it. Al-Zawahiri criticized Hamas arguing that it had legitimized "the secular leaders of Palestine [i.e., members of the secular PLO] who sold her for a pittance". He claimed that the idea of relinquishing Palestine contradicted the religion of Islam (al-Zawahiri, 2006a; 2006b). Hamas rejected al-Zawahiri's criticism and emphasized that it was not connected to any organization or group outside of Palestine and that there was no connection between the strategies of al-Qa'ida and Hamas (Anon, 2006a).

On April 23, 2006, following the freezing of international aid to the Palestinian Authority by Western governments, al-Jazeera aired another videotape of Usāmah Bin Lādin. This time Bin Lādin argued that the Hamas government stood at the front lines of a war being waged by the Crusaders and Zionists against Islam".

\footnotetext{
${ }^{7}$ During his tour of military duty as an IDF officer in the West Bank, the author of this essay was a witness to Hamas' ideological identification with Worldwide Jihad. See also, Maliach (2008, p. 358).

${ }^{8}$ Usāmah Bin Lādin, Waqi 'al-Ummah alIslamiyya (Reality of the Islamic Ummah). Location not available: Mu'assasat Al'ab lil-Intaj al-I'lami, 2002, Videotape.

9 The Hadith ("the hour for waking the dead will not arrive...") taken from Hanbal (1969, p. 417), Sahih Hadith (authentic hadith); Author's translation from the Arabic.
} 
At the time, Bin Lādin's statement was rejected by Hamas' spokespersons who claimed that the cessation of aid to the Palestinians would heighten the tensions on the Palestinian streets and the Arab world as a whole (Anon, 2006b).

\section{How to Free Palestine and Establish an Islamic Caliphate}

Both Hamas and al-Qaida believe that they have found the correct way to free Palestine and establish an Islamic Caliphate. In a letter from Ayman al-Zawahiri, ibn Lādin's deputy to Abu-Mus'ab al-Zarqawi, the leader of the al-Qaida movement in Iraq during that same period, al-Zawahiri wrote about an action plan that showed how al-Qaida also viewed the freeing of Palestine as a long-term, fitting objective that had to be prepared for effectively and intelligently in order for Israel, the creation of the West, to be destroyed. The content and the conclusions of Zawahiri's letter to Zarqawi are astonishing regarding al-Qaida's action plans and how amazingly similar they are to Hamas' goals and the ways to achieve them. This letter was captured when the Americans invaded al-Qaida bases in Iraq. It was publicized on an American information site in October 2005 in both the Arabic original version and with an English translation. Here are a few thoughts conveyed in the letter:

A comparison of al-Qaida's action plan to the Hamas action plan:

- First Stage: Expelling the Americans from Iraq.

- Second Stage: Establishing an Islamic authority or emirate, developing it and then supporting it until it achieves the level of a caliphate.

- Third Stage: Extending the wave of jihad in the secular countries neighboring Iraq.

- Fourth Stage: This coincides with what came before-a clash with Israel as Israel was only established to challenge the Islamic entity (Office of the Director of National Intelligence, 2005).

Hamas' plan is very similar. According to Hamas, the first stage began with Israel's withdrawal from the Gaza Strip in August 2005. The second stage began with the Hamas Revolution of 2007 when Hamas took over the administration of the Gaza Strip which is still going on, although the PA started operating in Gaza according to an agreement with Hamas (The Economist, 2017). The additional steps will take place in the future.

The similarity between the action plan procedures and the master plans does not necessarily mean agreement on how to reach those goals.

Zawahiri is sure that the ISIS state, when it will arise, will be in a constant state of warfare with the infidel forces which will desire to destroy it. The Hamas state, which was established after the expulsion of Fatah forces and the Palestinian Authority from the Strip, did the same thing.

In Ayman al-Zawahiri words to Abu-Mus'ab al-Zarqawi:

There is no doubt that this Emirate will enter into a fierce struggle with the foreign infidel forces and those supporting them among the local forces, to put it in a state of constant preoccupation with defending itself, to make it impossible for it to establish a stable state which could proclaim a caliphate and to keep the jihadist groups in a constant state of war until these forces find a chance to annihilate them. (Office of the Director of National Intelligence, 2005)

As Hamas also sees it, the mission is not only to expel the occupiers from the Gaza Strip-no matter if it is the United States or Israel-from specific areas but to continue to watch over the Islamic Emirs and to develop them up until the final victory. We can see this mindset from this picture whose caption was "The Cleansing of the Gaza Strip from Zionistic Settlements" which was publicized by Hamas after Operation Protective Edge in 2014. The Islamic emirs of Hamas, such as the Islamic State of ISIS, collect taxes, control 
shaaria, and rule over the population of this region which has been defined as "liberated" and work to expand it.

In the words of Aiman Zawahiri in his letter to al-Zarqawi, this idea was explicitly stated in regard to the relationship with an Islamic state:

And it is that the mujahedeen must not have their mission end with the expulsion of the Americans from Iraq and then lay down their weapons and silence the fighting zeal. We will return to having the secularists and traitors holding sway over us. Instead, their ongoing mission is to establish an Islamic state and defend it and for every generation to hand over the banner to the one after it until the Hour of Resurrection.

Zawahari, in his letter, also continues to emphasize the requirement of receiving public and popular support for the mujahedeen activities. The requirement to continue to gather support from the Palestinian public is, of course, something that Hamas has espoused since its founding through a complete dawah system whose goal is to recruit the Palestinian population for sacrifice and martyrdom (Levitt, 2006). The words of al-Zawahari seem to be taken straight from the Hamas doctrine: "If the jihadist movement was obliged to pursue other methods, such as a popular war of jihad or a popular intifada, then popular support would be a decisive factor between victory and defeat" (Office of the Director of National Intelligence, 2005).

Al-Zawahari, like Hamas, is well aware of the media's job on the battlefield. Already in 2001, Hamas established an internet site for the Palestinian Center of Information (Markaz al-Filastini lil-'Alam), al-Risalah, Filastin al-Muslima, etc. There are thousands of Facebook pages, all with different names, that are affiliated with the organization. During Operation Protective Edge, Hamas even added Hebrew articles to the Izz al-Din al-Qassam site. One can definitely say that the Hamas organization is a communications giant in the Palestinian-Arab-Islamic space. In the words of al-Zawahari:

I say to you: that we are in a battle and that more than half of this battle is taking place in the battlefield of the media. And that we are in a media battle in a race for the hearts and minds of our Umma. And that however far our capabilities reach, they will never be equal to one thousandth of the capabilities of the kingdom of Satan that is waging war on. (Office of the Director of National Intelligence, 2005)

There are three major areas where Hamas, al-Qaida, and ISIS agree:

1. A similar course of action in regard to the Islamic Caliphate.

2. The need for wide public support of the organization.

3. The great importance of the media.

\section{Disagreement Over a Way of Action}

Two of the well-known philosophers of Global Islam are Abu Muhammad al-Maqdisi and his pupil Abu Mus'ab al-Zarqawi's, the founder of al-Qaida in Iraq. Al-Maqdisi and Abu Musab al-Zarqawi formed an immediate bond - an alliance of the man of thought and the man of action. In 1993, they returned to Jordan to start an Islamist group. The following year both men were picked up by Jordanian authorities who seized their weapons-grenades and a machine gun—and imprisoned them. Abu Muhammad al-Maqdisi's decisions were often controversial. For instance, when Hamas began its suicide operations against Israel in 1994, Maqdisi denounced these attacks as un-Islamic, a position that Zarqawi supported at the time (Wright, 2006).

Despite this, Zarqawi later adopted the Hamas ways of action and even expanded them in a frightening manner that Hamas has not yet reached. It appears that there is a real disagreement on the topic of suicide 
terrorism between Hamas and al-Qaida.

The main disagreements between Hamas and the Global Jihad are on three planes:

1. The definition of the concept of "infidel forces" (takfir) and the legitimization of jihad against them.

2. The definition of jihad and its requirement. Is it a general requirement or a personal requirement? (fard'h kifaya or fard'h al-'ain)

3. Political considerations in carrying out jihad against Israel.

The first controversy is in regard to the question: On whom is it permitted to use jihad? If non-Muslims are mixed in with infidels or occupiers, is it permitted to carry out suicide attacks? In the eyes of al-Qaida and ISIS who have adopted the method of takfir (denoting excommunication-as one Muslim declaring another Muslim a non-believer-kafir), it is any society that acts in a non-Islamic way or which declares itself Muslim but cooperates with the enemy. This is a heretical society. Whoever is a part of it is not really Muslim, so it is permitted to kill them (Hafez, 2011). That is why, according to this world outlook which is explained here in simplistic terms: The Palestinian Authority is a fifth column and an enemy of Muslims. The Palestinian security forces are a fifth column and one must act against them as infidels (Baker, 2016). Hamas, of course, does not take this approach. Hamas strongly criticizes the Palestinian Authority for its security coordination with Israel but Hamas does not define the Authority and its organization as infidels. Hamas cooperates with the Popular Front for Liberation of Palestine (PFLP) and the Democratic Front (DFLP) on certain matters and does not define them as infidel organizations. In January 2006, after the Palestinian Authority elections in which the Hamas movement received the majority of seats, Hamas, together with Fatah, even established a unity government for a specific period of time under the presidency of Mahmoud Abas (Abu Mazen). Since July 2007, when Hamas took control of the Gaza Strip, a number of agreements have been signed between the Palestinian Authority, headed by Abas, and Hamas but still the without implementation (The Economist, 2017).

The division between the organizations is deep and basic. But Hamas does not work to destroy other groups in Muslim society-even if they are defined as secular, disagree with the organizations' opinions, or have contact and cooperate with the security forces of the Israeli occupation. Hamas' major jihad effort is aimed at Israel, the main enemy. Hamas participates in the Palestinian Authority elections as an additional political Islamic party as does Hezbollah. This is why world Islamic factors criticize Hamas (Walberg, 2015). Despite its criticism, Hamas succeeded in signing agreements with Salafi jihad organizations in Gaza based on jihad fighting against Israel (Baker, 2016).

Al-Qaida and ISIS are able to legitimize jihad against the enemy within, such as the Shiites and the moderate Sunnis from Tunisia who disagree with them or with various sectors, such as the Kurds in northern Iraq and Syria or the moderate Arab governments as they reject the belief that certain ideals can be compromised without hurting the principles of sharia (Baker, 2016).

Hamas acts against other groups in the Palestinian society only when they disagree with the rule or their rule in the Gaza Strip. They are careful not to call for an all-out war against the Palestinian Authority and the PLO despite the deep disagreements between them-especially when it comes to the strategic security cooperation with Israel.

An additional al-Qaida leader, Mohamed Hassan Qaid, called Abu Yahya al-Libi (who was assassinated in 2012), made a remark which didn't leave any doubt in regard to his stand on the Palestinian Authority: 
I swear to God, if it was not for the betrayal of these measly armies and the mobilization of their intelligence services by these secular, pagan countries and their absolute support to nations of infidelity-both western and eastern, the forces of the Christian and Jewish occupiers would have never been able to stay in Islamic lands all this time using [Muslim] resources, defiling their honor, embezzling their money and shedding their blood. (al-Libi, 2007; Hafez, 2011 p. 31)

\section{Who is Authorized to Declare Jihad?}

For generations, Muslim sages responsible for Muslim religious law were divided on who was permitted to declare jihad and under what circumstances. According to the fatw $\bar{a}^{10}$ of Abu Bakr al-Baghdadi, since the abolishment of the Islamic Caliphate, there is no Muslim "Leader of the Faithful" (Amir al-Mu'minin) able to call for jihad. That is why Abu Bakr, after the capture of Mosul in June 2014, announced in Mosul's main mosque that he was the Caliph and that he was declaring a jihad against the infidels. In other words, from now on jihad falls upon all Muslims worldwide who listen to his words and it is now an obligatory requirement on every one of the Islamic nations (Walberg, 2015).

According to the Hamas, the case of Palestine is a personal requirement (fard'h al-'ain). When an enemy, such as the Jews, invades Muslim lands and expels the residents of that same land, it is a personal duty of every Muslim to act against the invading infidels. The requirement is first of all to the residents of that same land, in other words the Palestinians, but it is up to the whole nation to help them in getting their stolen land back. That is exactly Abudlah Yusuf Azzam's (who was closely associated with Hamas) way of thinking, which he expressed in his book. His ideas were adopted by Hamas as their way of life up until today (Azzam, 1987).

\section{Political Considerations in Carrying out Jihad}

Israel and Hamas reached ceasefire agreements three times in regard to the area in the Gaza Strip. This was after a series of blood-filled battles which took place in 2008-2009, 2012, and 2014. In the framework of these understandings, Hamas committed to cease firing rockets toward Israel. These understandings earned serious criticism on the part of world jihad factors on how the Hamas organization dared to stop carrying out jihad against the Jewish invaders.

The understanding from Operation "Pillar of Defense" in November 2012 ended Hamas' firing of rockets toward Israel but the organizations Jund Ansar Allah (soldiers of the supporters' of Allah), Jaysh Al-Islam (Army of Islam), Jaysh Al-Umma (Army of the Nation), and al-Tawhid wal-Jihad (Monotheism and Jihad) which support al-Qaida and ISIS, continued to launch rockets and carry out anti-Israel activities. As a reaction, Hamas targets in the Gaza Strip were bombarded by Israel. In June 2013, Hamas sent 600 men to prevent, through the use of force, the Salafists groups of activists from shooting additional rockets toward Israel. In 2014, during Operation Protective Edge, al-Qaida activists also burned a Palestinian flag. This was to show that the war against Israel was not a nationalistic war but rather a religious one. In the eyes of global Islamic activists, the division of land into nationalistic countries is artificial and is part of the Western conspiracy to divide and conquer the Muslim world (Clarke, 2017).

The social media of the Islamic Salafists groups included the following items:

- Some jihadists or pro-jihadist Salafists issued video clips and tweets explaining their lack of assistance to the Palestinians. One tweet stated: "The Hamas government is apostate and what it is doing does not constitute jihad but rather a defense of democracy [which Salafists oppose]".

\footnotetext{
${ }^{10}$ Legal opinion or decree issued by a recognized authority and derived from Islam's roots of jurisprudence (usul al-fiqh).
} 
Another tweet said: "Khaled Meshaal: Hamas fights for the sake of freedom and independence. The Islamic state: It fights so that all religion can be for God (Mamouri, 2014)".

- The message is that "Hamas is not really a fighting force for Islam but is another infidel government acting against Islam and the word of God". The participation by Hamas in a democratic process is proof of the fact that Hamas even supports democracy and man-made laws. From this is the determination that there is no real difference between the rule of Hamas and any other Arab infidel rule, according to ISIS. That is why ISIS activists and al-Qaida are of the opinion that only after Hamas rule is replaced with a real legitimate Islamic rule does one need to turn to war with Israel (Clarke, 2017).

- On July 22nd, 2014 the Egyptian Salafist, Sheikh Talaat Zahran, declared that:

It was inappropriate to aid the people of Gaza because they did not follow legitimate leadership and because they are equivalent to Shiites since they follow them, [referring to Hezbollah and Iran, with which the Sunni Hamas movement has been allied].

Thus, the jihadists' position is not simply a political stance but stems from Salafist theological principles (Al-Bawabh [ISIS website], 2014).

It is important to indicate that Ismail Heniyeh criticized the death of Usāmah Bin Lādin and called him a martyr and one of the lions of Islam. In reality, he was almost the only Arab leader who criticized the American action of assassinating Bin Lādin in 2011 (Bartal, 2016).

The basic difference between the groups is that Hamas is more realistic and pragmatic than the jihadist Salafists. The former has political priorities in liberating Palestinian land whereas the latter have religious priorities in first establishing a totalitarian Islamic caliphate and only afterwards considering the Israeli issue as it is secondary to the central goal.

Hamas' political considerations stem mainly from its role as a social organization that runs an array of activities-dawah, monetary, and social support for the families of the terrorists and backing for the activists that support the organization. Hamas is not just a resistance organization, but it is also a political and social organization that needs mass public support and works among the masses in order to be dominant in the Palestinian society which it hopes to represent. Al-Qaida and ISIS see themselves as pioneer organizations that are joined by other Muslims whose goal is to renew the Caliphate and activities for the entire Islamic nation. ISIS does not convince those that oppose it to accept its opinion but it uses terror techniques in order to eliminate opposition. They believe that they are the real representatives of Islam and every true Muslim, according to their way of thinking, definitely wants them to rule. In light of this, ISIS and al-Qaida do not invest in a dawah system that will help draw in the masses but instead believe that their activities in the battlefield and their propaganda will attract the masses and those loyal to Islam to them.

Sheikh Yusuf Al-Qaraḍāwī who, since the death of Sheikh Ahmad Yassin, stands out as the spiritual leader of the Hamas organization, explains why he at first supported the suicide attacks of the second Palestinian intifada and why he is believes that such attacks no longer serve the Palestinian goals and has ruled to stop them:

I have allowed our brothers in Palestine to carry out such acts because of the special circumstances concerning defending their lives, the lives of their relatives, their children and their wives. [These circumstances] are what have forced them to be assisted by such acts that cannot be substituted. And I do not allow those acts anywhere else, with the exception of Palestine because of the lack of necessity that would obligate or allow that prohibition [to do so]. Therefore, making an analogy [regarding this matter] concerning Palestine to another country such as Algeria, Egypt, Yemen, Saudi Arabia, Iraq, 
Pakistan, etc., where Muslims carry out such acts against other Muslims is not acceptable. It is an analogy regarding an extraordinary case and is invalid as far as [Islamic] law is concerned. This also applies to those who carried out [attacks] against America on its territory, such as the events of 11 September 2001, that are not included in this exceptional permit.

[At present, in July 2015,] Allah has abolished the necessity for our brothers in Palestine for such acts, after it became possible for them to acquire missiles that strike deep into the territory of Israel, even though their quality is not as good as the Israeli missiles, they cause them damage and concern. Therefore, there is no longer justification for acts of sacrifice, as there was in the past. Every situation has its own law and its suitable statement and the fatwa changes according to changes in time, place and circumstance. (Al-Qaraḍāwi Website, 2015; MEMRI Website, 2015)

It is noteworthy that Qarậāwī qualifies his enthusiastic support for suicide attacks with two important warnings. First, suicide attacks may only be carried out in the case of Palestinians in their war against Israel. The special circumstances of military inferiority on the part of the Palestinians allow them to commit suicide attacks. He is afraid that Muslims throughout the world may infer that the permission granted to Palestinians would give them the right to commit such attacks against fellow Muslims. Secondly, if Palestinians possess an alternative weapon that can cause panic among Israelis, such as Qassām rockets, it is preferable to suicide attacks because of the harsh Israeli reaction to suicide attacks. Qaraḍāwī is aware of this and therefore, he does not want such acts to serve as a double-edged sword against the Palestinians ${ }^{11}$. For all intents and purposes, he permits Hamas and other Palestinian factions to launch rockets against civilian population centers, despite the fact that it is considered a war crime according to international law. This was also the conclusion of the inquiry commission of the United Nations after Operation Protective Edge (United Nations, Human Rights Council, 2015).

\section{Summary}

From the analysis above, one can see that it is incorrect to relate to the Hamas organization and the other organizations similar to it as national Islamic resistance movements to a foreign occupation. Branches of the Muslim brotherhood, some of which are violent toward the regime inside which they exist also exist in the Arab regimes, such as in Algeria and Egypt where the Muslim Brotherhood is defined as a terrorist organization. There is a lot in common between the Hamas organization, al-Qaida and ISIS in many aspects related to the Islamic faith, way of action and implementation and the final goal to which they aspire. Hamas describes itself as ashab al-haq wal shari'a wa-al-Islam (owners of the truth, the Islamic religious low and Islam) (Baker, 2016). This definition is common also to the other alafi global jihad organizations.

The differences between the different organizations are in the different emphasis given to practical nationalism, particularly on the way to achieve supreme control of the regime in the spirit of Hassan al-Banna, Sayid Qutb and Abdullah Azzam and the amount of national support that they hope to gain from the public among whom they are active. How to describe Hamas? Hamas is Salafi organization that is a part of the al-salafaiyya al-qataliyya groups like the other Global Jihad fighting organizations. Hamas has almost the same plan as al-Qaida-to destroy Israel, using the cult of martyrdom, using the same symbols and, in the end, having the same targets and goals as the Global Jihad organizations (first Palestine and then the other parts of the world as part of his global Muslim Brotherhood ideology). Hamas' roots are larger than Palestinian nationalism. Therefore, Hamas can be identified as a Global Jihad organization which combines national elements.

11 Al-Qarạ̣āwī, Fiqh al-Jihād, vol. 2, p. 1092. 


\section{References}

'Ali, A. (2004). Hilf al-Irhab, Tanzim al-Qā'ida min Abdu'llāh 'Azzām ila' Ayman az-Zawāhirī, 1979-2003 (The oath of terror, from the al-Qā'ida organization to Ayman az-Zawāhirī, 1979-2003). Cairo: Mahrusa.

'Azzam, A. (1987). Al-Difa 'an Aradi al-Muslimin Aham Furud al-A'yan (The defense of Muslim lands-The most important of individual obligations). Amman: Maktabat al-Risalah al-Hadithah.

'Azzam, A. (1990a). Hamas-Al-Judhur al-Ta'rikhiyyah wa-al-Mithaq (Hamas-Historical roots and the charter). Peshawar: Maktab Khadamat al-Mujahidin.

'Azzam, A. (1990b). Ilhaq bil-Qafilah (Join the Caravan). Sana: Maktabat al-Jil al-Jadid.

Al-Bawabh (ISIS Website). (2014). Bil-Fidio Sheikh Salafi: La yejuj Nasra Ahel Gaza la-Inhum Shi'a (On video, Sheikh Salafi: The people of Gaza will not get support becuse they are Shi'a). Retrieved from http://www.albawabhnews.com/697745

Al-Ghoul, A. (2014). Why won't Hamas label the Islamic state as terrorists? Retrieved from http://www.al-monitor.com/pulse/en/originals/2014/12/hamas-islamic-state-gaza-terrorist-attacks.html

Al-Libi, A. Y. (2007). Precious words in response to the critics of the Algerian Bombings (Arabic). Al-Fajr Media Center, Jul. 11, 2007.

Al-Qarạ̣āwi Website. (2015). Bayān taw đ̣̣ ḥ̂̄ ḥawla ra'y al-'Ullāma al-Qaraḍāwà fi-l-'amaliyyāt al-istishhādiyya (Clear manifestó of the religious leader al-Qaradawi about the suicide attack). Retrieved from http://Qarad̄āwi.net/new/takareer/8086-201507-27-13-42-39.

Al-Zawahiri, A. (2006a). Al-Zawahiri yantaqidu Hamas wa-yas 'adu dida al-gharb (Al-Zawahiri criticizes Hamas and rejects the West). Al-Jazeera, Mar. 5, 2006.

Al-Zawahiri, A. (2006b). Nas kalimat al-Zawahiri (Text of al-Zawahiri’s words). Al-Jazeera, Mar.5, 2006.

Anon. (2006a). Hamas tarfudu 'ard al-Zawahiri wa-mushaddah kalamiyyah bi-awwal ijtima' lil-Majlis alTashri 'i' (Hamas rejects al-Zawahiri's offer which leads to verbal scuffle during the first meeting of the legislative council). Retrieved from http://arabic.cnn.com/2006/middle_east/3/6/Hamas.qaeda

Anon. (2006b). Haniya: Bin Lädin tape shows solidarity. Retrieved from http://www.middle-east-online.com/english/Default.pl?id $1 / 416301$

Anon. (n.d.). Shahid al-Ummah alIslamiyyah al-Duktur 'Abdullah 'Azzam (The Islamic ummah's Martyr, Doctor 'Abdullah 'Azzam). Peshawar: Maktab Khadamat al-Mujahidin.

Azzam, A. Y. (1987). Al-Diff'a an Aradi al-Muslamin Aham Farud al-Aaiyan (The defense of Muslim lands-The most important of individual obligations). Amman: Maktabat al-Risalah al-Haditha.

Baker, B. A. (2016). Al-salafaiyya wa-Da'ash fi Ghaza? Wa-Hamas (The Salafi movement and ISIS in Gaza? and Hamas). Retrieved

from https://www.europarabct.com/\%D8\%A7\%D9\%84\%D8\%B3\%D9\%84\%D9\%81\%D9\%8A\%D8\%A9-\%D9\%88\%D8\%AF\%D 8\%A7\%D8\%B9\%D8\%B4-\%D9\%81\%D9\%8A-\%D8\%BA\%D8\%B2\%D8\%A9\%D8\%9F-\%D9\%88\%D8\%AD\%D9\%85\%D8 $\% \mathrm{~A} 7 \% \mathrm{D} 8 \% \mathrm{~B} 3 /$

Bartal, S. (2011). The Fedayeen emerge, the Palestine-Israel conflict, 1949-1956. Bloomington: AuthorHouse.

Bartal, S. (2016). Jihad in Palestine, political Islam and the Israeli-Palestinian conflict. Abingdon: Rutledge.

Bartal, S. (2017a). Jew-hatred in Islamic state organization's (ISIS) ideology. Cultural and Religious Studies Journal, $5,165-177$.

Bartal, S. (2017b). New forms of Palestinian terror against Israel: A profile of the Al-Quds Intifada. New York: Mellen Press.

Bartal, S. (2018). Hamas and ideology, Sheikh Yusuf al-Qaradawi on the Jews, Zionism and Israel. Abingdon: Rutledge.

Bin Lādin, U. (2001). Al-Nas al-kamil li-Hadith Bin Lādin 'abra al-Jazeera (The full text of Bin Lādin's words through al-Jazeera). Al-Jazeera, Dec. 27, 2001.

Calvert, J. (2010). Sayyid Qutb: The origins of radical Islam. London: Hurst and Co.

Chehab, Z. (2007). Inside Hamas: The untold story of militants, martyrs and spies. London: I.B. Tauris \& Co Ltd.

Clarke, C. P. (2017). How Salafism's rise threatens Gaza. Retrieved from https://www.rand.org/blog/2017/10/how-salafisms-rise-threatens-gaza.html

Dalacoura, K. (2011). Islamist terrorism and democracy in the Middle East. New York: Cambridge University Press, 2011.

Efraim, O. (2016). Deri asks to revoke citizenship, residency of two ISIS operatives. Retrieved from https://www.ynetnews.com/articles/0,7340,L-4820653,00.html

Hafez, M. M. (2011). Takfir and violence against Muslims. In A. Moghadam \& B. Fishman (Eds.), Fault lines in Global Jihad, organizational, strategic, and ideological fissures (pp. 26-28). Abingdon, UK: Routledge. 
Hanbal, A. I. (1969). Musnad Ahmad Ibn Hanbal (Anthology of the hadiths of Ahmad Ibn Hanbal) (Vol. 2). Beirut: al-Maktab al-Islami.

Heggehammer, T. (2008). Abdallah Azzam, the Imam of Jihad. In G. Kepel \& J. P. Milelli (Eds.), Al-Qā'ida in its own words (pp. 81-101). Cambridge: Harvard University Press.

Hegghammer, T. (2013). 'Abdallāh 'Azzām and Palestine. Die Welt Des Islams, 53, 376-378.

Itani, T. (2014). Quran, English Translation. Beirut: ClearQuran Dallas.

Levitt, M. (2006). Hamas: Politics, charity and terrorism in the service of Jihad. New Haven/London: Yale University Press.

Maliach, A. (2008). Bin Lādin, Palestine and al-Qa'ida's operational strategy. Middle Eastern Studies, 44(3), 353-375.

Mamouri, A. (2014). Why Islamic state has no sympathy for Hamas. Retrieved from http://www.al-monitor.com/pulse/originals/2014/07/islamic-state-fighting-hamas-priority-before-israel.html\#\#ixzz3CceTOuKY

MEMRI Website. (2015). Sheikh Qaradawi: The Palestinians have no need for suicide attacks since they have missiles. Retrieved from http://www.memri.org.il/cgi-webaxy/sal/sal.pl?lang=he\&ID=875141_memri\&act=show\&ddbid=articles\&dataaid=3931

Office of the Director of National Intelligence. (2005). Letter from al Zawahiri to Zarqawi. Retrieved from https://fas.org/irp/news/2005/10/dni101105.html

Shabi, A., \& Shaked, R. (1994). Hamas. Jerusalem: Keter.

Singh, R. (2011). Hamas and suicide terrorism: Multi-casual and multi-level approaches. Abingdon: Routledge.

The Economist. (2017). The Palestinians try to reconcile. Retrieved from https://www.economist.com/news/middle-east-and-africa/21730026-latest-effort-likely-fail-palestinians-try-reconcile

United Nations, Human Rights Council. (2015). Report of the independent commission of inquiry established pursuant to HRC Resolution $S-21 / 1$. Geneva: United Nations.

Walberg, E. (2015). Islamic resistance to imperialism. Atlanta, GA: Clarity Press.

Wright, L. (2006). For the new theorists of Jihad, Al Qaeda is just the beginning. Retrieved from http://www.newyorker.com/magazine/2006/09/11/the-master-plan 